ductive one, the number of productive nodes and pods per node, paying attention not only to their total number and pairing, but also to the presence and plumpness of beans on the upper productive nodes. We also measure the seed number per pod. In $\mathrm{F}_{3}$, offspring is assessed for evenness and the vegetation phase lengths. In $\mathrm{F}_{4-5}$, only even high-yielding families are selected; they are threshed; and the total number of seeds is estimated. General requirements for the selection of hybrid and breeding material depend only on the direction of breeding.

Conclusions. The application of the pedigree method in pea breeding is time-consuming for breeders and demands thoroughness at all stages. However, this approach allows detailed investigating hybrid material at the beginning of the breeding process, which increases the breeding effectiveness. The effectiveness of the applied methods and selection ways is confirmed by demand for pea varieties bred at the Plant Production Institute named after VYa Yuriev and positive feedback from manufacturers.

Key words: pea, breeding, selection, early generation, hybrid population, genetic control of a trait, productivity

\title{
WAXY BARLEY STARCH AS RAW MATERIAL FOR HEALTHY FOOD PRODUCTS
}

Vasko N.I. ${ }^{1}$, Kozachenko M.R. ${ }^{1}$, Naumov O.G. ${ }^{1}$, Solonechnyi P.M. ${ }^{1}$, Vazhenina O.E. ${ }^{1}$, Solonechna O.V. ${ }^{1}$, Pozdniakov V.V. ${ }^{1}$, Sheliakina T.A. ${ }^{1}$, Ilchenko N.K. ${ }^{1}$, Suprun O.G. ${ }^{1}$, Serik M.L. ${ }^{2}$

${ }^{1}$ Plant Production Institute nd. a. V.Ya. Yuriev of NAAS, Ukraine

${ }^{2}$ State University of Food Technology and Trade, Ukraine

The article justifies the expediency of the breeding of barley cultivars with waxy starch, grain of which can be raw material for functional food production. The study purpose was to create food barley cultivars with waxy starch. To accomplish this, qualitative parameters of barley accessions were determined, and starting material was selected for breeding. The study was conducted at the Plant Production Institute named after V.Ya. Yuriev of NAAS in 2015-2017. Twenty four chaffy and naked barley accessions of different origin were taken as the test material. Grain quality parameters of wild type and waxy accessions were compared. The yield, protein and starch contents, endosperm vitreousness, and antioxidant activity were shown to depend both on growing conditions and on genotypes. High nutritional quality of waxy barley cultivars was proved, videlicet, significantly higher content of oil compared with accessions with wild type starch and lower vitreousness of endosperm in chaffy accessions. Accessions with very valuable characteristics were selected: line 12-1014 with high digestibility of protein $(61.75 \mathrm{mg}$ tyrosine $/ \mathrm{g}$ protein for pepsinolysis + trypsinolysis), line 12-945 with high antioxidant activity $(2.02 \mathrm{mg}$ chlorogenic acid equivalent/g), line 12-954 with a high content of oil (3.75\%) and awnless line 14-1183 with a high content of polyunsaturated $\omega-3$ linolenic acid $(6.09 \%)$. These lines are valuable both as starting material for the breeding of food cultivars, and directly for functional food production. Waxy cultivars Shedevr and Amil were submitted to the state variety trials. Grain of these cultivars is noticeable for high contents of starch (>60\%), oil (3.45-3.47\%) and fiber (3.65$3.70 \%$ ). Antioxidant activity is also sufficiently high (1.94-2.07 mg chlorogenic acid equivalent $/ \mathrm{g}$ ). Being low vitreous (40-43\%), cultivars Shedevr and Amil can be used for production of flakes and flour, including extruded flour.

(C) N.I. Vasko, M.R. Kozachenko, O.G. Naumov, P.M. Solonechnyi, O.E. Vazhenina, O.V. Solonechna, V.V.Pozdniakov, T.A. Sheliakina, N.K. Ilchenko, O.G. Suprun, M.L. Serik. 2019.

ISSN 1026-9959. Селекція і насінництво. 2019. Випуск 115. 
Key words: waxy starch, barley, amylose, amylopectin, antioxidant activity, protein content and digestibility, fatty acid composition of oil

Introduction. Recently, the interest in barley grain as raw material for food products has been increasing due to its positive impact on human health. Such products lower cholesterol levels in blood, regulate the glycemic index and antioxidant activity [1]. They counteract the three most lethal diseases of the present - cardiovascular diseases, cancer and diabetes. In particular, these diseases are associated with free radical formation, and barley grain exerts a high antioxidant effect. This is especially true for waxy barley, starch of which consists of $95-100 \%$ amylopectin [2]. Therefore, creation of waxy barley cultivars that will be suitable for functional food production is an important area of barley breeding.

Starch is a major component of barley grain, as it accounts for over $70 \%$ of dry matter [3, 4] and determines its nutritional and technological properties. Starch content was found to vary in barley grain. For example, the total content of starch varied $45.7 \%$ to $66.4 \%$ in 112 Chinese barley cultivars [5]. The starch content ranged $58.1 \%$ to $72.2 \%$ in 10 Canadian genotypes [4]. The starch content in seeds of 39 barley genotypes was within $51.3 \%-64.2 \%$ [6].

In grain of most barley cultivars, starch contains $72-78 \%$ of amylopectin, the other component is amylose. The recessive allele of the wax gene almost completely blocks amylose synthesis, and its content varies $20-25 \%$ to $0-5 \%$ related to wild type starch. In the world's assortment of barley, two functional alleles and one null allele or wax allele of the wax gene were identified $[7,8]$. The wax gene is localized in chromosome $1(7 \mathrm{H})$. Genotypes with normal (3:1 amylopectin : amylose) starch composition have the dominant Wax gene [9, 10]. A genetic marker was developed for the wax gene, and it is effectively used in breeding programs [11].

In addition, the wax gene is associated with an increase in contents of potent antioxidants, $\beta$-glucans, in grain of naked and chaffy barley on average by $4.85 \%-6.1 \%$ [12]. There are a lot of data on stable dependence of antioxidant activity on the genotype $[13,14,15]$. However, there are reports that in some waxy genotypes genetic factors reducing contents of $\beta$-glucans were identified. Researchers attribute this phenomenon to thin walls of endosperm cells [16].

The amylose content in barley starch varies $0 \%$ to $5 \%$ in waxy barley, $20-30 \%$ in wild type accessions and is around $45 \%$ in high amylose barley [17]. The ratio of the major structural components of starch can be changed genetically. Changes in this ratio increase the content of dietary fiber, affecting functional characteristics of the gastrointestinal tract and human body in general, consequently, increasing the nutritional value of barley grain. Waxy barleys have increased levels of simple sugars (glucose, fructose, sucrose) and soluble fiber represented by $\beta$ glucans in comparison with wild type ones. The contents of $\beta$-glucans and oil are higher by $40 \%$ and $25 \%$, respectively, in barley with the wax allele compared with wild type [2].

Currently, there are cultivars with starch containing 95-100\% of amylopectin (waxy barley) or 40-70\% of amylose (high amylose barley) [18]. The first waxy barley cultivars were created in Canada and Sweden, with cultivar Azhul as the initial one, as well as in Japan by chemical mutagenesis $[12,19,20]$.

Currently, the breeding of food barley, mainly naked barley with waxy starch, is extensively conducted in Canada. Waxy cultivars with high contents of $\alpha$-glucans (CDC Alamo, CDC Ascent, Enduro, CDC Fibar, CDC Rattan, CDC Marlina) are known. Analogous cultivars are also bred in Japan. Two-row naked cultivar Kirari-mochi was created; its starch entirely consists of amylopectin (waxy, amylose-free). Being highly nutritional, Kirari-mochi is suitable for groat production [21].

Work on creation of barley cultivars with various amilopectin / amylose ratios in starch is widely deployed in the Czech Republic. Genotypes with increased contents of starch are used in food production. Statistical differences in yields were revealed between cultivars with wild type and waxy starch. For example, the average yield of waxy cultivars (4.9 t/ha) was significantly lower than that of wild type ones $(5.7 \mathrm{t} / \mathrm{ha})$. The protein content was significantly higher in waxy cultivars than in wild type ones (12.1\% vs. $11.5 \%$ ) [22]. In another study on 30 barley accessions, there was a positive correlation between the protein content and the percentage of long chains of 
amylopectin, while the correlation between the protein content and the percentage of long chains of amylose was negative [23].

The Department of Genetic Foundations of Breeding of the Plant Breeding and Genetics Institute of NAAS created breeding lines with high performance, including waxy ones, with technological parameters of grain suitable for production of a wide range of products: with hard grain for production of flour, groats, noodles, pasta and with soft grain for production of flakes and drinks. Commercial Canadian naked cultivars Alamo and Candle served as sources of the wax gene $[2,24]$.

The Plant Production Institute named after V.Ya. Yuriev of NAAS breeds waxy barley with lines UA 0804955 (Belarus), UA 039699, UA 039701, U.S. 039748 (USA), and IR 6912 (Mexico) as the sources of the wax gene. Other breeding components were domestic cultivars. As a result, high-performance and adapted to local growing conditions lines with waxy starch were created $[25,26]$.

Barley is used in healthy food production due to its positive effects on human health [27]. Oxidative stress and inflammation are two key factors that contribute to atherosclerosis development. Studies of barley, in particular, of its protective function in regulation of antioxidant protection, revealed powerful protective features of barley in oxidative processes and the potential role of barley in preventing chronic inflammation in cardiovascular diseases [28]. Japanese researchers reported that consumption of waxy barley groats improved the intestine functioning, especially in the elderly [29].

Food products made from barley grain or flour with various amylopectin / amylose ratios considerably differ in technological properties and quality. Products made from waxy barley are characterized by reduced hardness compared to products made from wild type barley. Tortillas from waxy barley are better rolled and less fragile [17].

Thus, the starch properties have a significant impact on the food quality, and creation of barley cultivars with modified amilopectin / amylose ratios is essential for healthy food production.

Purpose and objective. The study purpose was to create waxy barley cultivars suitable for functional food production. For this purpose, quality parameters of barley accessions were determined and starting material was selected for breeding.

Materials and methods. The study was conducted at the Plant Production Institute named after V.Ya. Yuriev of NAAS. Twenty four chaffy and naked barley accessions of different origin with waxy and wild type starch were taken as the test material. Cultivar Vzirets, which is the best in the zone of our investigations, was taken as the standard.

The data were statistically processed by analysis of variance; a posteriori comparison was performed using homogeneous groups (Fisher LSD test) in software STATISTICA 10. Relationships between traits were evaluated using correlation and regression coefficients.

The protein and starch contents were measured on an InfraLUM FT-10M 09495. vitreousness was determined on a diaphanoscope. Waxy genotypes were identified by dyeing with Lugole's iodine solution (modified Juliano's method). Starch granules of waxy barley are discolored to dark red or brown, and wild type starch granules - to dark-blue [30].

The antioxidant activity (AOA) of barley accessions was evaluated by capacity of ethanol extracts to neutralize the DPPH (2,2-diphenyl-1-picyrylhydrazyl) radical. The method is based on discoloration of ethanol solution of the stable DPPH $\bullet$ in the presence of ethanol extracts of grain products containing antioxidants that are proton donors capable of neutralizing the DPPH radical and translate it into a decolorized reduced form. The antiradical activity was determined as described by S. Arabshahi and A. Urooj [31].

The in vitro ability of protein to be digested by proteolytic enzymes was determined by $\mathrm{O}$. Pokrovsky and I. Ertanove's method, which consists in gradual action of proteinases (crystalline pepsin and trypsin) on proteins [32].

Results and discussion. Weather conditions are important to obtain top-quality raw materials. For example, there is evidence that high temperature during ear formation increases the protein content and decreases the starch content in grain, depending on the genotype. There is also evidence that waxy genotypes are more responsive to high temperatures than wild type ones [33]. 
The weather conditions during the study period were various; however, they were favorable for the growth and development of barley plants in the "emergence-tillering" phase. In 2015, there was a drought in the crucial phases of earing and grain filling, and in 2016 an excessive amount of precipitation caused plant lodging during this period (Table 1).

Table 1

Weather conditions during the development periods of spring barley

\begin{tabular}{|c|c|c|c|c|c|c|c|c|c|c|c|c|}
\hline \multirow[b]{3}{*}{ Year } & \multicolumn{3}{|c|}{ Emergence-tillering } & \multicolumn{3}{|c|}{$\begin{array}{l}\text { Tillering-ear } \\
\text { formation }\end{array}$} & \multicolumn{3}{|c|}{$\begin{array}{l}\text { Ear-formation-grain } \\
\text { filling }\end{array}$} & \multicolumn{3}{|c|}{$\begin{array}{c}\text { Grain } \\
\text { filling-ripening }\end{array}$} \\
\hline & & $\sum$ & & & $\sum$ & & & $\sum$ & & & $\sum$ & \\
\hline & $\begin{array}{l}\sum \text { ef. } \\
t^{\circ} \mathrm{C}\end{array}$ & $\begin{array}{c}\text { preci- } \\
\text { pitati- } \\
\text { on, } \\
\text { mm }\end{array}$ & HTC & $\begin{array}{l}\Sigma \text { ef. } \\
t^{\circ} \mathrm{C}\end{array}$ & $\begin{array}{c}\text { preci- } \\
\text { pitati- } \\
\text { on, } \\
\text { mm }\end{array}$ & HTC & $\begin{array}{l}\Sigma \text { ef. } \\
\mathrm{t}^{\circ} \mathrm{C}\end{array}$ & $\begin{array}{c}\text { preci- } \\
\text { pitati- } \\
\text { on, } \\
\mathrm{mm}\end{array}$ & HTC & $\begin{array}{l}\Sigma \text { ef. } \\
\mathrm{t}^{\circ} \mathrm{C}\end{array}$ & $\begin{array}{c}\text { preci- } \\
\text { pitati- } \\
\text { on, } \\
\text { mm }\end{array}$ & HTC \\
\hline 2015 & & 46.4 & & 162 & 7.0 & 0 & 350 & 30.0 & & & 117.1 & 1.76 \\
\hline 2016 & 243 & 69.0 & 2.8 & 222 & 119.0 & 5.36 & 263 & 38.0 & 1.4 & 559 & 102.0 & 1.82 \\
\hline 2017 & 327 & 39 & 1.19 & 277 & 33 & 1.19 & 277 & 9 & 0.32 & 719 & 37 & 0.51 \\
\hline
\end{tabular}

The yields of barley accessions were the highest in 2017 and the lowest in 2015, which is accounted for the weather conditions during the "ear formation" and "grain flilling" phases, however, no significant difference in the yields was noticed over the years. The performance of the naked cultivars significantly differed from that of chaffy ones, both in the group with wild type starch and in the waxy group (Table 2). The lower yield of naked cultivars is due to the absence of glume, which makes up $8-10 \%$ of the grain weight. The yields of waxy accessions were lower than those in the group with wild type starch, but this difference was not significant. Thus, in our study, the yields of waxy accessions are similar to those of accessions with wild type starch, which is at odds with other researchers ${ }^{\text {ee }}$ results [22].

Table 2

Yields of barley accessions, t/ha

\begin{tabular}{|c|c|c|c|c|}
\hline \multirow{2}{*}{ Type of accessions } & \multicolumn{4}{|c|}{ Yield } \\
\hline & 2015 & 2016 & 2017 & Average \\
\hline \multicolumn{5}{|c|}{ Chaffy with wild type starch } \\
\hline mean & 4.90 & 4.89 & 6.08 & 5.29 \\
\hline $\max$ & 5.16 & 5.45 & 6.65 & 5.75 \\
\hline $\min$ & 4.73 & 4.28 & 5.63 & 4.88 \\
\hline \multicolumn{5}{|c|}{ Chaffy with waxy starch } \\
\hline mean & 4.71 & 4.68 & 5.67 & 5.02 \\
\hline $\max$ & 5.08 & 5.35 & 6.18 & 5.54 \\
\hline $\min$ & 4.47 & 3.99 & 5.09 & 4.52 \\
\hline \multicolumn{5}{|c|}{ Naked with wild type starch } \\
\hline mean & 3.38 & 3.47 & 4.35 & 3.73 \\
\hline $\max$ & 3.90 & 4.25 & 4.75 & 4.30 \\
\hline $\min$ & 3.11 & 2.77 & 3.85 & 3.24 \\
\hline \multicolumn{5}{|c|}{ Chaffy with waxy starch } \\
\hline mean & 2.89 & 3.38 & 4.17 & 3.48 \\
\hline $\max$ & 3.05 & 3.67 & 4.48 & 3.73 \\
\hline $\min$ & 2.65 & 3.03 & 3.85 & 3.18 \\
\hline $\mathrm{LSD}_{05}$ & 0.38 & 0.34 & 0.33 & \\
\hline
\end{tabular}

Footnote. Significance level $\mathrm{P} \geq 0.95$. 
Grain quality for food production is primarily determined by protein and starch contents. Proteins are extremely important for the human body, since they belong to essential irreplaceable substances. In our study, the protein content was significantly higher in naked cultivars both with waxy $(14.30 \%)$ and wild type (14.03\%) starch (Table 3$)$. There was no significant difference in the protein content between chaffy cultivars with wild type and waxy starch $(12.41 \%$ and $12.34 \%$. respectively). In other studies [22, 23], the protein content was significantly higher in all waxy accessions. i.e. our data are consistent with these results.

There was no significant difference in the starch content between the groups of accessions $(59.52 \%, 60.32 \%, 60.80 \%, 59.53 \%)$ (see Table 3). Depending on the year conditions. the starch content was significantly higher in 2016 compared with the other years. This is in line with the literature data indicating that low temperature during "ear formation-grain filling" period increases the starch content [33].

Table 3

Protein and starch contents in grain of barley accessions, \%

\begin{tabular}{|c|c|c|c|c|c|c|c|c|}
\hline \multirow{2}{*}{$\begin{array}{l}\text { Type of } \\
\text { acces- } \\
\text { sions }\end{array}$} & \multicolumn{4}{|c|}{ Protein content } & \multicolumn{4}{|c|}{ Starch content } \\
\hline & 2015 & 2016 & 2017 & Average & 2015 & 2016 & 2017 & Average \\
\hline \multicolumn{9}{|c|}{ Chaffy with wild type starch } \\
\hline mean & 12.88 & 12.21 & 12.15 & 12.41 & 57.90 & 61.54 & 59.13 & 59.52 \\
\hline $\max$ & 13.24 & 12.97 & 12.56 & 12.92 & 59.67 & 63.49 & 60.41 & 61.19 \\
\hline $\min$ & 11.86 & 10.59 & 11.28 & 11.24 & 56.94 & 59.30 & 57.69 & 57.81 \\
\hline \multicolumn{9}{|c|}{ Chaffy with waxy starch } \\
\hline mean & 12.42 & 12.65 & 11.95 & 12.34 & 58.73 & 62.08 & 60.14 & 60.32 \\
\hline $\max$ & 14.31 & 14.02 & 13.47 & 13.93 & 59.82 & 62.78 & 61.20 & 61.27 \\
\hline $\min$ & 10.33 & 11.05 & 10.33 & 10.57 & 57.88 & 60.77 & 59.21 & 59.29 \\
\hline \multicolumn{9}{|c|}{ Naked with wild type starch } \\
\hline mean & 14.22 & 13.90 & 13.98 & 14.03 & 57.97 & 64.27 & 60.16 & 60.80 \\
\hline $\max$ & 17.40 & 15.85 & 15.22 & 16.16 & 59.27 & 67.15 & 63.29 & 63.24 \\
\hline $\min$ & 13.65 & 12.46 & 12.03 & 12.71 & 54.80 & 62.95 & 58.72 & 58.82 \\
\hline \multicolumn{9}{|c|}{ Naked with waxy starch } \\
\hline mean & 14.27 & 13.61 & 15.03 & 14.30 & 56.50 & 62.19 & 59.89 & 59.53 \\
\hline $\max$ & 14.76 & 14.47 & 16.74 & 15.32 & 57.11 & 64.18 & 60.34 & 60.54 \\
\hline $\min$ & 13.74 & 12.59 & 13.96 & 13.43 & 56.00 & 58.70 & 59.04 & 57.91 \\
\hline $\mathrm{LSD}_{05}$ & & & & 0.35 & & & & 2.42 \\
\hline
\end{tabular}

Footnote. Significance level $\mathrm{P} \geq 0.95$.

In addition to protein content in foods, one should know the level of protein absorption by the human body. This parameter is determined by the biological value of protein, which depends on the presence of essential amino acids, their ratio to nonessential ones and digestibility in the gastrointestinal tract. Enzymatic hydrolysis can be carried out in conditions close to the conditions of digestion in a living organism, which is a biochemical method for assessing protein digestibility. In this case, in vitro attackability of proteins is determined, which gives the complex characterization of the protein under investigation compared to the reference (casein). We distinguished waxy line 12-1014 by the amount of soluble products of pepsinolysis and trypsinolysis (61.75 $\mathrm{mg}$ tyrosine/g protein). Other lines and cultivars had significantly lower digestibility than that of line 12-1014 (Table 4).

According to the current requirements to food barley cultivars, they are expected to have vitreous endosperm. Vitreousness is an external trait of the grain quality; it reflects the structure of internal tissues of grain. In ripe barley grain, starchy endosperm cells are filled with starch granules immersed in the protein matrix. For floury endosperm, weak bonds between starch grainules and proteins are intrinsic. In vitreous endosperm, such bonds are very strong. Vitreousness is influenced by growing conditions during the "grain filling" and "ripening" phases: the more frequent dry days are, the higher this index is. Vitreous grain usually contains more protein than floury one. 
In vitro digestibility of waxy barley proteins by gastrointestinal digestive enzymes, 2017

\begin{tabular}{lccc}
\hline \multirow{2}{*}{ Accession } & \multicolumn{2}{c}{ Amounts of soluble products of proteinolysis, mg tyrosine/g protein } \\
\cline { 2 - 4 } & Pepsinolysis & Trypsinolysis & $\begin{array}{c}\text { Pepsinolysis }+ \\
\text { trypsinolysis }\end{array}$ \\
\hline Amil & 9.15 & 34.65 & 43.80 \\
CDC Alamo & 7.70 & 39.60 & 47.30 \\
$12-954$ & 15.95 & 21.00 & 36.95 \\
$12-952$ & 11.15 & 28.70 & 39.85 \\
$12-1014$ & 14.85 & 46.90 & $\mathbf{6 1 . 7 5}$
\end{tabular}

Footnote. Significance level: $\mathrm{n}=5, \mathrm{P} \geq 0.95, \varepsilon \leq 5$.

In our study, the vitreousness of chaffy cultivars was significantly lower $(49 \%, 51 \%)$ than that of naked ones $(94 \%, 88 \%)$. At the same time, waxy cultivars had a lower vitreousness than wild type cultivars, but this difference was insignificant (Table 5). Thus, having soft grain, waxy accessions are suitable for production of flour, including extruded flour, and flakes.

Table 5

Endosperm vitreousness in barley accessions, \%

\begin{tabular}{|c|c|c|c|c|}
\hline \multirow{2}{*}{ Type of accessions } & \multicolumn{4}{|c|}{ Vitreousness } \\
\hline & 2015 & 2016 & 2017 & Average \\
\hline \multicolumn{5}{|c|}{ Chaffy with wild type starch } \\
\hline mean & 51 & 44 & 59 & 51 \\
\hline $\max$ & 56 & 53 & 80 & 63 \\
\hline $\min$ & 48 & 32 & 45 & 42 \\
\hline \multicolumn{5}{|c|}{ Chaffy with waxy starch } \\
\hline mean & $47^{\circ}$ & 51 & 49 & 49 \\
\hline $\max$ & 49 & 56 & 54 & 53 \\
\hline $\min$ & 36 & 25 & 41 & 34 \\
\hline \multicolumn{5}{|c|}{ Naked with wild type starch } \\
\hline mean & 92 & 94 & 96 & 94 \\
\hline $\max$ & 99 & 99 & 99 & 99 \\
\hline $\min$ & 84 & 90 & 91 & 88 \\
\hline \multicolumn{5}{|c|}{ Naked with waxy starch } \\
\hline mean & 84 & 86 & 97 & 89 \\
\hline $\max$ & 94 & 99 & 100 & 98 \\
\hline $\min$ & 65 & 67 & 93 & 75 \\
\hline
\end{tabular}

Footnote. Significance level $\mathrm{P} \geq 0.95$.

The effects of the growing conditions during the crucial phases of vegetation on endosperm vitreousness in spring barley cultivars were investigated. The precipitation during the "ear formation - grain filling" period reduced vitreousness, especially in naked cultivars $(\mathrm{r}=-0.846)$. There was only a positive tendency between the sum of effective temperatures in the "ear formation - grain filling" phase and vitreousness in chaffy cultivars, while in naked ones there was a significant positive correlation ( $\mathrm{r}=0.803$ ).

Rise in temperature in the "grain filling - ripening" phase significantly increases endosperm vitreousness, with the correlation coefficient ranging within 0.526-0.875. The dependence of vitreousness on the precipitation amount in the "grain filling - ripening" phase is insignificant, since a negative tendency was only observed. This is accounted for the fact that in the research area precipitation is usually very rare and showery during the "grain filling - ripening" period in barley, which can not significantly affect the parameters under investigation. 
The antioxidant activity is a major factor determining the value of food for human health. The level of this parameter in barley is one of the highest among cereals. We found that the antioxidant activity depended both on the genotype and on the conditions of cultivation and analysis type. Thus, the highest AOA was recorded in 2016, the lowest - in 2015 (Table 6). At the same time, there was a steady dependence of the AOA on the genotype, which is consistent with numerous data of other researchers $[13,14,15]$. Under any conditions, the AOA was the highest in naked genotypes with waxy starch. This parameter had no significant differences within the other groups of accessions, with the lowest values in chaffy accessions with wild type starch (see Table 6).

Table 6

Antioxidant activity of barley accessions, mg chlorogenic acid equivalent/g

\begin{tabular}{lcccc}
\hline \multirow{2}{*}{ Type of accessions } & \multicolumn{4}{c}{ Antioxidant activity } \\
\cline { 2 - 4 } mean & 2015 & 2016 & 2017 & Average \\
\hline max & Chaffy with wild type starch & \\
min & 1.07 & 2.33 & 2.21 & 1.87 \\
& 1.25 & 2.84 & 2.42 & 2.17 \\
mean & 1.01 & 1.63 & 1.98 & 1.54 \\
max & Chaffy with waxy starch & \\
min & 1.06 & 2.57 & 2.22 & 1.95 \\
& 1.12 & 2.84 & 2.43 & 2.13 \\
mean & 1.00 & 1.99 & 2.06 & 1.68 \\
max & Naked with wild type starch & & \\
min & 1.01 & 2.74 & 2.29 & 2.01 \\
& 1.21 & 2.99 & 2.83 & 2.34 \\
mean & 0.85 & 2.44 & 2.08 & 1.79 \\
max & Naked with waxy starch & & \\
min & 1.14 & 3.14 & 2.37 & 2.22 \\
\hline & 1.29 & 3.46 & 2.60 & 2.45 \\
\hline
\end{tabular}

Footnote. Significance level $\mathrm{P} \geq 0.95$.

It should be noted that among all the accessions the highest AOA was in naked cultivar Alamo (up to $3.46 \mathrm{mg}$ chlorogenic acid equivalent/g), which is considered the reference for this parameter in the world.

According to the literature data, genetic factors that control the waxy trait can be associated with genetic factors that increase the lipid content in barley [12, 34]. Our results are consistent with these data. The oil content in grain of waxy accessions is significantly higher (2.92-3.52\%) than that both in chaffy $(2.55 \%)$ and in naked $(2.53 \%)$ accessions with wild type starch (Table 7$)$. Among the waxy accessions, the oil content is significantly higher in chaffy accessions (3.52\%) compared to naked ones $(2.92 \%)$.

After burning barley grain, organic carbon-free ash, which is a concentrate of grain minerals, remains. We found that the ash content was, expectedly, significantly higher in chaffy accessions. This parameter does not depend on starch composition. The fiber content is of great importance for the digestive processes. Total fiber, as a complex of nutritional value, consists of insoluble and soluble components. We revealed that the average content of fiber in waxy accessions was higher than that in wild type ones, but the difference was insignificant (Table 7). This is only partially consistent with other researchers ${ }^{\text {ee }}$ results $[12,35,36]$.

As a part of vegetable oils, including barley oil, unsaturated fatty acids are very important for healthy human nutrition. Barley oil is different from others by high levels of such acids, in particular, of polyunsaturated $\omega-3$ linolenic acid. In our study, the linolenic acid content was the highest in chaffy cultivars with wild type starch bred at the Plant Production Institute nd. a V.Ya. Yuriev of NAAS: in Lider (6.64\%), Krasen (6.52\%), Vzirets (6.50\%), and Ahrarii (6.30\%). 
Oil, ash and fiber contents in grain of barley accessions, \% (2017)

\begin{tabular}{lccc}
\hline \multicolumn{1}{r}{ Type of accessions } & Oil content & Ash content & Fiber content \\
\hline \multirow{4}{*}{ mean } & Chaffy with wild type starch & \\
max & 2.55 & 2.29 & 4.19 \\
min & 2.88 & 2.40 & 5.03 \\
& 2.07 & 2.17 & 3.08 \\
mean & Chaffy with waxy starch & \\
max & 3.52 & 2.11 & 4.32 \\
min & 3.75 & 2.35 & 4.90 \\
& 3.35 & 1.83 & 3.65 \\
mean & Naked with wild type starch & \\
max & 2.53 & 1.66 & 2.13 \\
min & 3.08 & 1.78 & 2.85 \\
& 2.02 & 1.45 & 1.70 \\
mean & Naked with waxy starch & \\
max & 2.92 & 1.74 & 2.19 \\
min & 3.04 & 1.80 & 2.33 \\
\hline & 2.80 & 1.68 & 2.05 \\
\hline
\end{tabular}

Of the waxy barley lines and cultivars, the highest contents of polyunsaturated fatty acids were found in cultivar Shedevr (linolenic acid 5.85\%, linoleic acid 54.68\%), awnless line 141183 (linolenic acid 6.09\%), and naked cultivar Candle (linoleic acid 54.80\%) (Table 8).

Table 8

Fatty acid composition of oil in waxy barley grain, methyl esters of fatty acids, $\%$ related to the sum

\begin{tabular}{|c|c|c|c|c|c|c|c|c|c|c|}
\hline \multirow{2}{*}{$\begin{array}{c}\text { Acces- } \\
\text { sion }\end{array}$} & $\begin{array}{c}\text { Myri- } \\
\text { stic }\end{array}$ & $\begin{array}{l}\text { Myri- } \\
\text { stoleic }\end{array}$ & $\begin{array}{c}\text { Palmi- } \\
\text { tinic }\end{array}$ & $\begin{array}{c}\text { Palmit- } \\
\text { oleic }\end{array}$ & $\begin{array}{l}\text { Stea- } \\
\text { rinic }\end{array}$ & Oleic & $\begin{array}{l}\text { Lino- } \\
\text { leic }\end{array}$ & $\begin{array}{l}\text { Linol- } \\
\text { enic }\end{array}$ & $\begin{array}{c}\text { Arachi- } \\
\text { donic }\end{array}$ & $\begin{array}{l}\text { Eico- } \\
\text { senic }\end{array}$ \\
\hline & $\mathrm{C} 14: 0$ & C14:1 & C16:0 & C16:1 & C18:0 & C18:1 & C18:2 & C18:3 & C20:0 & C20:1 \\
\hline Vzirets & 0.81 & 0.67 & 21.78 & 0.65 & 1.26 & 14.82 & 52.24 & 6.50 & 0.43 & 0.06 \\
\hline Shedevr & 0.19 & - & 20.68 & 0.30 & 1.39 & 16.28 & 54.68 & 5.85 & 0.23 & 0.10 \\
\hline $12-954$ & 0.37 & 0.22 & 19.85 & 0.28 & 1.19 & 18.80 & 53.35 & 5.29 & 0.29 & 0.09 \\
\hline $14-1183$ & 0.61 & 0.45 & 21.28 & 0.42 & 1.01 & 16.53 & 53.05 & 6.09 & 0.21 & 0.06 \\
\hline $\begin{array}{l}\text { CDC } \\
\text { Candle }\end{array}$ & 0.21 & - & 20.63 & 0.40 & 1.44 & 16.78 & 54.80 & 5.12 & 0.22 & 0.07 \\
\hline $\begin{array}{l}\text { CDC } \\
\text { Alamo } \\
\end{array}$ & 0.22 & - & 21.00 & 0.38 & 1.51 & 18.55 & 52.75 & 5.13 & 0.22 & 0.07 \\
\hline
\end{tabular}

The waxy lines with the best quality and economic parameters were submitted to the state variety trials: lines 12-473 and 12-476 called Shedevr and Amil, respectively. The yields of these lines amount to $5.38-5.43 \mathrm{t} / \mathrm{ha}$, which is higher by $8-12 \%$ than that of standard Vzirets. The protein content is medium; the starch content is high $(>60 \%)$ (Table 9). The oil content $(3.45-3.47 \%)$ and fiber content (3.65-3.70\%) are high. The antioxidant activity is also sufficiently high (1.94$2.07 \mathrm{mg}$ chlorogenic acid equivalent/g). Grain of cultivars Shedevr and Amil is characterized by low vitreousness (40-43\%), therefore, it is suitable for production of flakes and flour, including extruded flour.

The lines of high nutritional quality of grain are used in breeding as starting material for hybridization. Cultivars Shedevr and Amil were submitted to the state variety trials. 
Characteristics of waxy barley cultivars (2015-2017)

\begin{tabular}{ccccccccc}
\hline & \multicolumn{8}{c}{ Indication } \\
\cline { 2 - 8 } Cultivar & $\begin{array}{c}\text { Yield, } \\
\text { t/ha }\end{array}$ & $\begin{array}{c}\text { Protein } \\
\text { content, } \\
\%\end{array}$ & $\begin{array}{c}\text { Starch } \\
\text { content, } \\
\%\end{array}$ & $\begin{array}{c}\text { Vitreous- } \\
\text { ness, } \%\end{array}$ & $\begin{array}{c}\text { Oil } \\
\text { content, } \\
\%\end{array}$ & $\begin{array}{c}\text { Ash } \\
\text { content, } \\
\%\end{array}$ & $\begin{array}{c}\text { Fiber } \\
\text { content, } \\
\%\end{array}$ & $\begin{array}{c}\text { Antioxi- } \\
\text { dant ac- } \\
\text { tivity, } \\
\mathrm{mg} / \mathrm{g}\end{array}$ \\
\hline Shedevr & 5.43 & 11.13 & 60.11 & 43 & 3.45 & 3.20 & 3.65 & 1.94 \\
Amil & 5.38 & 12.70 & 60.66 & 40 & 3.47 & 3.21 & 3.70 & 2.07 \\
\hline
\end{tabular}

Conclusions. Thus, as a result of the study, high nutritional qualities of grain of barley waxy cultivars were demonstrated. In particular, such barley genotypes have significantly higher oil contents than wild type accessions, and their endosperm is less vitreous in chaffy accessions. Several accessions with very valuable characteristics were selected: line 12-1014 with a high protein digestibility (61.75 $\mathrm{mg}$ tyrosine/g protein for pepsinolysis + trypsinolysis), line 12-945 with a high antioxidant activity (2.02 $\mathrm{mg}$ chlorogenic acid equivalent/g). Line 12-954 was singled out due to the oil content (3.75\%); awnless line $14-1183$ - due to a high content of polyunsaturated $\omega-3$ linolenic acid in oil $(6.09 \%)$. Such lines are valuable both as starting material for the breeding of food cultivars and directly for functional food production. Having appropriate economic and qualitative parameters, cultivars Shedevr and Amil can be used for production of flakes and flour.

\section{References}

1. Baik B.K., Ulrich S.E. Barley for food: characteristics, improvement, and renewed interest. J. Cereal Sci. 2008; 48: 233-242. DOI: 10.1016/j.jcs.2008.02.002.

2. Rybalka O.I., Morgun B.V., Polishchuk S.S. Barley as a product of functional nutrition. Kyiv: Logos, 2016. $620 \mathrm{p}$.

3. Zhu F. Barley starch: composition, structure, properties, and modifications. Comprehensive Reviews in Food Science and Food Safety. 2017; 16(4): 558-579. DOI: 10.1111/15414337.12265.

4. Asare E.K., Jaiswal S., Maley J., Båga M., Sammynaiken R., Rossnagel B.G., Chibbar R.N. Barley grain constituents, starch composition, and structure affect starch in vitro enzymatic hydrolysis. J. Agric. Food Chem. 2011; 59: 4743-4754. DOI: 10.1021/jf200054e.

5. Ping H., Wang J., Ren G. Prediction of the total starch and amylase content in barley using near-infrared reflectance spectroscopy. Intell. Autom. Soft Co. 2013; 19: 231-237.

6. Holtekjølen A.K., Uhlen A.K., Brathen E., Sahlstrøm S., Knutten S.H. Contents of starch and non-starch polysaccharides in barley varieties of different origin. Food Cnem. 2006; 94: 348358.

7. Polishchuk S., Morgun B., Rybalka O. Polymorphism of the genes Bmyl, Lox-1 and Wax as determinants of nutritional value of barley grain. Zbirnyk naukovykh prats SGI-NTsNS. 2014; 24: 28-40.

8. Stepanenko E.V., Stepanenko A.I., Rybalka A.I., Morgun B.V., Kuzminskii E.V. Detection of allelic variants of the gene $\operatorname{Wax}$ in domestic and foreign barley varieties.Nauchnyie vesti NTU UKPI. 2014; 3: 78-83.

9. Vasanthan T., Hoover R. Barley starch: production, properties, modification and uses. In: Starch: chemistry and technology. Elsevier Inc., 2009. P. 601-628.

10. Nilan R. The cytology and genetics of barley 1951-1962. Washington State University, Pullman, WA. 1964.

11. Fan X., Sun Yu., Zhu J., Ly Ch., Guo B., Xu R. A 191-bp insertion/deletion in $G B S S_{1}$ region is responsible for the changes in grain amylose content in barley (Hordeum vulgare L.). Molecular Breeding. 2017; 37: 81-90. DOI: 10.1007/s11032-017-0677-X.

12. Xue J., Wang R., Newman C., Graham H. Influence of the hulless, waxy starch, and shortawn genes on the composition of barley. J. Cereal Sci. 1997; 26: 251-257. 
13. Maillard M.N., Boivin P., Soum M.H., Berset C. Antioxidant activity of barley and malt: relationship with phenolic content. Food Science and Technology. 1996; 29(3): 238-244. DOI: 10.1006/fst.1996.0035.

14. Simic G., Horvat D., Dvojkovic K., Abicic J., Viljevac Vuletic M., Tucak M., Lalic A. Evaluation of total phenolic content and antioxidant activity of malting and hulless barley grain and malt extracts. Czech. J. Food Sci. 2017; 35(1): 73-78. DOI: 10.17221/144/2016-CJFS.

15. Zhigang Han, Jingjie Zhang, Shengguan Cai, Xiaohui Chen, Xiaoyan Quan, Guoping Zhang. Association mapping for total polyphenol content, total flavonoid content and antioxidant activity in barley. BMC Genomics. 2018; 19: 81-90. DOI: 10.1186/S12864-018-4483-6.

16. Sanston J., Ellis R., Tiller S. Effects of the waxy and high-amylose genes on the total betaglucan and extractable starch. Barley Genet. Newsletter. 1997; 27: 72-74.

17. Ulrich S.E. Barley in food production. In trasl. N. Ulianitskaia. Zerno. 2010; 12. Available at: www.zerno-ua/com.

18. Vasanthan T., Hoover R. Barley starch: production, properties, modification and uses. In: Starch: chemistry and technology. Elsevier Inc., 2009. P. 601-628.

19. Bhatty R., Rossnagel B. Zero amylase lines of hulless barley. Cereal Chem. 1997; 74: 190191.

20. Ajithkumar A., Anderson R., Christerson T., Aman P. Amylose $\beta$-glucan content of new waxy barleys. Starch/Stärke. 2005; 57: 235-239.

21. Yanagisawa T., Nagamine T., Takahashi A., Takayama T., Doi Y., Matsunaka H., Fujita M. Breeding of Kirari-mochi: Anew two-rowed waxy hull-less barley cultivar with superior quality characteristics. Breeding Science. 2011; 61: 307-310. DOI: 10.1270/jsbbs.61.307.

22. Balounová M., Vaculová K., Hložková L., Mikuliková R., Ehrenbergerová J. The effect of the changed amylose and amylopectin ratio on the selected qualitative parameters in spring barley (Hordeum vulgare L.) grain. Acta Universitatis Agriculturae et Silviculturae Mendelinae Brunensis. 2013; LXI(3): 577-585. DOI: 10.11118/actaun201361030577.

23. Yu W., Tan X., Zou W., Hu Zh., Fox GP., Gidley MJ., Gilbert R.G. Relationships between protein content, starch molecular structure and grain size in barley. Carbohydrate Polymers. 2017; 155: 271-279.

24. Kirdoglo E.K., Polishchuk S.S., Chervonis M.V. Methodology and results of breeding narley for food end-use. Trudy po prikladnoy botanike, genetike I selektsii. T. 171. Geneticheskiie resursy ovsa, pzhy, yachmenia. Sankt-Peterburg: VIR, 2013. P. 240-253.

25. Naumov O.G., Kozachenko M.R., Vasko N.I., Solonechnyi P.M., Vazhenina O.E. Waxy barley breeding. Sel. Nasinn. 2014; 105: 60-69. DOI: 10.30835/2413-7510.2014.42052.

26. Kozachenko M.R., Naumov O.G., Vasko N.I., Solonechnyi P.M., Solonechna O.V., Vazhenina O.E., Sadovoy O.O. Breeding of new waxy barley lines. Factors in experimental evolution of organisms. 2016; 18: 93-96.

27. Stanca A.M., Gianetti A., Rizza F., Terzi V. Barley: an overview of aversatile cereal grain with many food and feed uses. In: Wrigley C.W., Corke H., Seetharaman K., Faubion J., editors. Encyclopedia of food grains. 2016. $2^{\text {nd }}$ ed. Oxford: Elsevier. P. 147-152. DOI: 10.1016/B978-0-12-394437-5.00021-8.

28. Liao Zh., Cai H., Xu Z., Wang J., Qiu Ch., Xie J., Huang W., Sui Zh. Protective role of antioxidant huskless barley extracts of TNF- $\alpha$-Induced endothelial dysfunction in human vascular endothelial cells. Oxidative medicine and cellular longevity. 2018. (10 pages). DOI: $10.1155 / 2018 / 3846029$.

29.Taniguchi K., Komae K., Takahashi A., Yoshioka T., Sone Y. Effect of waxy barley, Kirarimochi, consumption on bowel movements of late-stage residents at Roken nursing home. J. Physiol. Anthropol. 2017; 36: 17. DOI: 10.1186/s40101-017-0131-0.

30. Mac Gregor A., Fincher G. Carbohydrate of the barley grain. In: Barley: Chemistry and technology. A.W. Mac Gregor, R.S. Bhatty, eds. American Association of Cereal Chemists, St. Paul, MN, 1993. P. 73-130.

31. Arabshahi S., Urooj A. Antioxidant properties of various solvent extracts of mulberry Morus indica L. Leaves. Food Chem. 2007; 102: 1233-1240. 
32. Pokrovskiy A.A., Ertanov I.V. In vitro digestibility of food proteins by proteolityc enzym. Voprosy pitaniia. 1965; 1: 38-44.

33. Reinhardt D., Jansen G., Sedding S., Eichler-Löbermann B. Temperature stress during flowering time affects yield and quality parameters of waxy barley. Appl. Agric. Forestry Res. 2013; 1(63): 79-84. DOI: 10.3220/LBF_2013_79-84.

34. Lobo V., Patil A., Phatak A., Chandra N. Free radicals, antioxidants and functional foods: impact of human health. Pharmacol. Rev. 2010; 4(8): 118-126.

35. Åman P., Newman C. Chemical composition of some different types of barley grown in Montana, USA. J. Cereal Sci. 1986; 4: 133-141.

36. Han M., Froseth I. Composition of pearling fractions of barleys with normal and waxy starch. Proc. West. Sec. Amer. Anim. Sci. 1992; 43: 155-158.

\section{Список використаних джерел}

1. Baik B.K., Ulrich S.E. Barley for food: characteristics, improvement, and renewed interest. J. Cereal Sci. 2008. № 48. P. 233-242. DOI: 10.1016/j.jcs.2008.02.002.

2. Рибалка О.І., Моргун Б.В., Поліщук С.С. Ячмінь як продукт функціонального харчування. Київ: Логос, 2016. 620 с.

3. Zhu F. Barley starch: composition, structure, properties, and modifications. Comprehensive Reviews in Food Science and Food Safety. 2017. № 16(4). P. 558-579. DOI: 10.1111/15414337.12265.

4. Asare E.K., Jaiswal S., Maley J., Båga M., Sammynaiken R., Rossnagel B.G., Chibbar R.N. Barley grain constituents, starch composition, and structure affect starch in vitro enzymatic hydrolysis. J. Agric. Food Chem. 2011. № 59. P. 4743-4754. DOI: 10.1021/jf200054e.

5. Ping H., Wang J., Ren G. Prediction of the total starch and amylase content in barley using near-infrared reflectance spectroscopy. Intell. Autom. Soft Co. 2013. № 19. P. 231-237.

6. Holtekjølen A.K., Uhlen A.K., Brathen E., Sahlstrøm S., Knutten S.H. Contents of starch and non-starch polysaccharides in barley varieties of different origin. Food Cnem. 2006. № 94. P. 348-358.

7. Поліщук С., Моргун Б., Рибалка О. Поліморфізм генів Bmy1, Lox-1 та Wax як детермінантів ознак харчової цінності зерна ячменю. Збірник наукових праць СГІ-НЦНС. 2014. Вип. 24. С. 28-40.

8. Степаненко Е.В., Степаненко А.И., Рыбалка А.И., Моргун Б.В., Кузьминский Е.В. Выявление аллельных вариантов гена $W a x$ среди отечественных и зарубежных сортов ячменя. Научные вести НТУ УКПИ. 2014. № 3. С. 78-83.

9. Vasanthan T., Hoover R. Barley starch: production, properties, modification and uses. In: Starch: chemistry and technology. Elsevier Inc., 2009. P. 601-628.

10. Nilan R. The cytology and genetics of barley 1951-1962. Washington State University, Pullman, WA. 1964.

11. Fan X., Sun Yu., Zhu J., Ly Ch., Guo B., Xu R. A 191-bp insertion/deletion in $G B S S_{l}$ region is responsible for the changes in grain amylose content in barley (Hordeum vulgare L.). Molecular Breeding. 2017. № 37. P. 81-90. DOI: 10.1007/s11032-017-0677-x.

12. Xue J., Wang R., Newman C., Graham H. Influence of the hulless, waxy starch, and shortawn genes on the composition of barley. J. Cereal Sci. 1997. № 26. P. 251-257.

13. Maillard M.N., Boivin P., Soum M.H., Berset C. Antioxidant activity of barley and malt: relationship with phenolic content. Food Science and Technology. 1996. № 29(3). P. 238-244. DOI: $10.1006 /$ fst.1996.0035.

14. Simic G., Horvat D., Dvojkovic K., Abicic J., Viljevac Vuletic M., Tucak M., Lalic A. Evaluation of total phenolic content and antioxidant activity of malting and hulless barley grain and malt extracts. Czech. J. Food Sci. 2017. № 35(1). P. 73-78. DOI: 10.17221/144/2016CJFS.

15. Zhigang Han, Jingjie Zhang, Shengguan Cai, Xiaohui Chen, Xiaoyan Quan, Guoping Zhang. Association mapping for total polyphenol content, total flavonoid content and antioxidant activity in barley. BMC Genomics. 2018. № 19. P. 81-90. DOI: 10.1186/S12864-018-4483-6. 
16. Sanston J., Ellis R., Tiller S. Effects of the waxy and high-amylose genes on the total betaglucan and extractable starch. Barley Genet. Newsletter. 1997. № 27. P. 72-74.

17. Ульрих С.Е. Ячмень в производстве продуктов питания. Перевод Н. Ульяницкой. Зерно. 2010. № 12. www.zerno-ua/com.

18. Vasanthan T., Hoover R. Barley starch: production, properties, modification and uses. In: Starch: chemistry and technology. Elsevier Inc., 2009. P. 601-628.

19. Bhatty R., Rossnagel B. Zero amylase lines of hulless barley. Cereal Chem. 1997. № 74. P. 190-191.

20. Ajithkumar A., Anderson R., Christerson T., Aman P. Amylose $\beta$-glucan content of new waxy barleys. Starch/Stärke. 2005. № 57. P. 235-239.

21. Yanagisawa T., Nagamine T., Takahashi A., Takayama T., Doi Y., Matsunaka H., Fujita M. Breeding of Kirari-mochi: Anew two-rowed waxy hull-less barley cultivar with superior quality characteristics. Breeding Science. 2011. № 61. P. 307-310. DOI: 10.1270/jsbbs.61.307.

22. Balounová M., Vaculová K., Hložková L., Mikuliková R., Ehrenbergerová J. The effect of the changed amylose and amylopectin ratio on the selected qualitative parameters in spring barley (Hordeum vulgare L.) grain. Acta Universitatis Agriculturae et Silviculturae Mendelinae Brunensis. 2013. T. LXI(3). P. 577-585. DOI: 10.11118 /actaun201361030577.

23. Yu W., Tan X., Zou W., Hu Zh., Fox GP., Gidley MJ., Gilbert R.G. Relationships between protein content, starch molecular structure and grain size in barley. Carbohydrate Polymers. 2017. № 155. P. 271-279.

24. Кирдогло Е.К., Полищук С.С., Червонис М.В. Методология и результаты селекции ячменя пищевого использования. Труды по прикладной ботанике, генетике и селекции. Том 171. Генетические ресурсы овса, ржи, ячменя. Санкт-Петербург: ВИР, 2013. С. 240-253.

25. Наумов О.Г., Козаченко М.Р., Васько Н.І., Солонечний П.М., Важеніна О.С. Селекція waxy-ячменю. Селекція і насінництво. 2014. Вип. 105. С. 60-69. DOI: 10.30835/24137510.2014.42052.

26. Козаченко М.Р., Наумов О.Г., Васько Н.І., Солонечний П.М., Солонечна О.В., Важеніна О.С., Садовой О.О. Селекція нових ліній ячменю шаху. Фактори експериментальної еволюції організмів. 2016. Т. 18. С. 93-96.

27. Stanca A.M., Gianetti A., Rizza F., Terzi V. Barley: an overview of aversatile cereal grain with many food and feed uses. In: Wrigley C.W., Corke H., Seetharaman K., Faubion J., editors. Encyclopedia of food grains. 2016. $2^{\text {nd }}$ ed. Oxford: Elsevier. P. 147-152. DOI: 10.1016/B978-0-12-394437-5.00021-8.

28. Liao Zh., Cai H., Xu Z., Wang J., Qiu Ch., Xie J., Huang W., Sui Zh. Protective role of antioxidant huskless barley extracts of TNF- $\alpha$-Induced endothelial dysfunction in human vascular endothelial cells. Oxidative medicine and cellular longevity. 2018. (10 pages). DOI: $10.1155 / 2018 / 3846029$.

29.Taniguchi K., Komae K., Takahashi A., Yoshioka T., Sone Y. Effect of waxy barley, Kirarimochi, consumption on bowel movements of late-stage residents at Roken nursing home. J. Physiol. Anthropol. 2017. № 36. P. 17. DOI: 10.1186/s40101-017-0131-0.

30. Mac Gregor A., Fincher G. Carbohydrate of the barley grain. In: Barley: Chemistry and technology. A.W. Mac Gregor, R.S. Bhatty, eds. American Association of Cereal Chemists, St. Paul, MN, 1993. P. 73-130.

31. Arabshahi S., Urooj A. Antioxidant properties of various solvent extracts of mulberry Morus indica L. Leaves. Food Chem. 2007. № 102. P. 1233-1240.

32. Покровский А.А., Ертанов И.В. Атакуемость белков пищевых продуктов протеолитическими ферментами in vitro. Вопросы питания. 1965. № 1. С. 38-44.

33. Reinhardt D., Jansen G., Sedding S., Eichler-Löbermann B. Temperature stress during flowering time affects yield and quality parameters of waxy barley. Appl. Agric. Forestry Res. 2013. T. 1(63). P. 79-84. DOI: 10.3220/LBF_2013_79-84. 
34. Lobo V., Patil A., Phatak A., Chandra N. Free radicals, antioxidants and functional foods: impact of human health. Pharmacol. Rev. 2010. T. 4(8). P. 118-126.

35. Åman P., Newman C. Chemical composition of some different types of barley grown in Montana, USA. J. Cereal Sci. 1986. № 4. P. 133-141.

36. Han M., Froseth I. Composition of pearling fractions of barleys with normal and waxy starch. Proc. West. Sec. Amer. Anim. Sci. 1992. T. 43. P. 155-158.

\section{СОРТИ ЯЧМЕНЮ 3 ШАХУ-КРОХМАЛЕМ ЯК СИРОВИНА ДЛЯ ПРОДУКЦЇ ЗДОРОВОГО ХАРЧУВАННЯ}

${ }^{1}$ Васько Н.І., ${ }^{1}$ Козаченко М.Р., ${ }^{1}$ Наумов О.Г., ${ }^{1}$ Солонечний П.М., ${ }^{1}$ Важеніна О.С., ${ }^{1}$ Солонечна О.В., ${ }^{1}$ Поздняков В.В., ${ }^{1}$ Шелякіна Т.А. ${ }^{1}$ Ільченко Н.К., ${ }^{1}$ Супрун О.Г., ${ }^{2}$ Сєрік М.Л.

${ }^{1}$ Інститут рослинництва ім. В.Я. Юреє єваНААН, Україна

2 Державний університет харчування та торгівлі, Україна

У статті обгрунтовано доцільність селекції сортів ячменю з шаху-крохмалем, зерно яких може бути сировиною для виробництва продуктів функціонального харчування.

Мета дослідження. Метою дослідження було створення харчових сортів ячменю 3 waхукрохмалем. Для цього було визначено показники якості зразків ячменю та виділено вихідний матеріал для селекції.

Матеріали та методи. Дослідження проведено в Інституті рослинництва ім. В.Я. Юр єва НААН у 2015-2017 рр. Вихідним матеріалом були 24 плівчастих та голозерних зразки ярого ячменю різного походження.

Обговорення результатів. У результаті дослідження проведено порівняння показників якості зерна зразків зі звичайним та шаху-крохмалем. Установлено залежність урожайності, вмісту білка, крохмалю, склоподібності ендосперму, антиоксидантної активності як від умов вирощування, так і від генотипу. Встановлено високу поживну якість зерна таких сортів - істотне перевищення вмісту олії у порівнянні із зразками зі звичайним крохмалем, більш низька склоподібність ендосперму плівчастих зразків. Виділено окремі зразки з дуже цінними характеристиками - лінія 12-1014 з високою перетравлюваністю білка (61,75 мг тирозину на 1 г білка за сумою пепсинолізу і трипсинолізу), лінія 12-945 з високою антиоксидантною активністю (2,02 мг/г за еквівалентом хлорогенової кислоти), лінія 12-954 за вмістом олії (3,75 \%) та безоста лінія 14-1183 за вмістом поліненасиченої $\omega-3$ ліноленової кислоти (6,09 \%). До Державного сортовипробування передано сорти 3 шаху-крохмалем Шедевр і Аміл. Зерно цих сортів має високий вміст крохмалю (понад 60 \%), олії (3,45-3,47 \%) та клітковини (3,65-3,70 \%). Достатньо високою $\epsilon$ антиоксидантна активність (1,94-2,07 мг/Г за еквівалентом хлорогенової кислоти). За низькою склоподібністю (40-43 \%) сорти Шедевр і Аміл можуть бути використаними для виробництва пластівців та борошна, в тому числі екструдованого.

Висновки. Таким чином, установлено високу харчову цінність сортів ячменю з крохмалем зміненого складу. Виділено лінії з високим вмістом поживних речовин, які $є$ цінними і як вихідний матеріал для селекції харчових сортів, так і безпосередньо для виготовлення продуктів функціонального харчування. До Державного сортовипробування передано сорти Шедевр і Аміл, Шедевр внесений до Державного реєстру сортів рослин, придатних для поширення в Україні з 2019 р.

Ключові слова: ячмінь, селекція, жаху-крохмаль, амілоза, амілопектин, антиоксидантна активність, вміст та перетравлюваність білка, жирнокислотний склад олії 


\section{СОРТА ЯЧМЕНЯ С ШАХУ-КРАХМАЛОМ КАК СЫРЬЕ ДЛЯ ПРОДУКТОВ ЗДОРОВОГО ПИТАНИЯ}

${ }^{1}$ Васько Н.И., ${ }^{1}$ Кириченко В.В., ${ }^{1}$ Кобызева Л.Н., ${ }^{1}$ Козаченко М.Р., ${ }^{1}$ Наумов А.Г.,

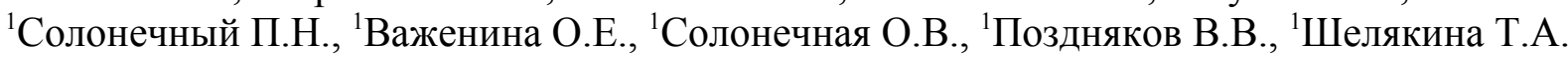
${ }^{1}$ Ильченко Н.К., ${ }^{1}$ Супрун О.Г., ${ }^{2}$ Серик М.Л.

${ }^{1}$ Институт растениеводства им. В.Я. Юрьева НААН, Украина

${ }^{2}$ Государственный университет питания и торговли, Украина

В статье обоснована целесообразность селекции сортов ячменя с шаху-крахмалом, зерно которых может быть сырьем для производства продуктов функционального питания.

Цель исследования. Целью исследования было создание пищевых сортов ячменя с waxyкрахмалом. Для этого были определены показатели качества образцов ячменя и выделен исходный материал для селекции.

Материалы и методы. Исследования проведены в Институте растениеводства им. В.Я. Юрьева НААН в 2015-2017 гг. Исходным материалом были 24 пленчатых и голозерных образца ярового ячменя различного происхождения.

Обсуждение результатов. В результате исследования проведено сравнение показателей качества зерна образцов с обычным и шаху-крахмалом. Определена зависимость урожайности, содержания белка, крахмала, стекловидности эндосперма, антиоксидантной активности как от условий выращивания, так и от генотипа. Установлены высокие питательные качества зерна таких сортов - существенно более высокое содержание масла в сравнении с образцами с обычным крахмалом, более низкая стекловидность эндосперма пленчатых образцов. Выделены отдельные образцы с очень ценными характеристиками - линия 12-1014 с высокой переваримостью белка (61,75 мг тирозина на 1 г белка по сумме пепсинолиза и трипсинолиза), линия 12-945 с высокой антиоксидантной активностью (2,02 мг/г по эквиваленту хлорогеновой кислоты), линия 12-954 по содержанию масла (3,75 \%) и безостая линия 14-1183 по содержанию полиненасыщенной $\omega-3$ линоленовой кислоты $(6,09$ \%). В Государственное сортоиспытание переданы сорта с wаху-крахмалом Шедевр и Амил. Зерно этих сортов характеризуется высоким содержанием крахмала (свыше 60 \%), масла (3,45-3,47 \%) и клетчатки (3,65-3,70 \%). Достаточно высокой является антиоксидантная активность (1,94-2,07 мг/г по эквиваленту хлорогеновой кислоты). По низкой стекловидности (40-43 \%) сорта Шедевр и Амил могут быть использованы для производства хлопьев и муки, в тому числе экструдированной.

Выводы. Таким образом, установлена высокая пищевая ценность сортов ячменя с крахмалом измененного состава. Выделенные линии, характеризующиеся высоким содержанием питательных веществ, являются ценными и как исходный материал для селекции пищевых сортов, так и непосредственно для изготовления продуктов функционального питания. В Государственное испытание переданы сорта Шедевр и Амил, Шедевр внесен в Государственный реестр с 2019 г.

Ключевые слова: ячмень, селекция, жаху-крахмал, амилоза, амилопектин, антиоксидантная активность, содержание и переваримость белка, жирнокислотньй состав масла 


\section{WAXY BARLEY STARCH AS RAW MATERIAL FOR HEALTHY FOOD PRODUCTS}

${ }^{1}$ Vasko N.I., ${ }^{1}$ Kozachenko M.R., ${ }^{1}$ Naumov O.G., ${ }^{1}$ Solonechnyi P.M., ${ }^{1}$ Vazhenina O.E., ${ }^{1}$ Solonechna O.V., ${ }^{1}$ Pozdniakov V.V., ${ }^{1}$ Sheliakina T.A., ${ }^{1}$ Ilchenko N.K., ${ }^{1}$ Suprun O.G., ${ }^{2}$ Serik M.L.

${ }^{1}$ Plant Production Institute nd. a. V.Ya. Yuriev of NAAS, Ukraine

${ }^{2}$ State University of Food Technology and Trade, Ukraine

Purpose and objective. The study purpose was to create waxy barley cultivars suitable for functional food production. For this purpose, quality parameters of barley accessions were determined and starting material was selected for breeding.

Materials and methods. The study was conducted at the Plant Production Institute named after V.Ya. Yuriev of NAAS in 2015-2017. Twenty four chaffy and naked barley accessions of different origin with waxy and wild type starch were taken as the test material.

The data were statistically processed by analysis of variance; a posteriori comparison was performed using homogeneous groups (Fisher LSD test) in software STATISTICA 10. Relationships between traits were evaluated using correlation and regression coefficients.

The protein and starch contents were measured on an InfraLUM FT-10M 09495, vitreousness was determined on a diaphanoscope. Waxy genotypes were identified by dyeing with Lugoles iodine solution (modified Juliano's method). The antioxidant activity (AOA) of barley accessions was evaluated by capacity of ethanol extracts to neutralize the DPPH (2,2-diphenyl-1picyrylhydrazyl) radical. The antiradical activity was determined as described by S. Arabshahi and A. Urooj. The in vitro ability of protein to be digested by proteolytic enzymes was determined by O. Pokrovsky and I. Ertanov's method, which consists in gradual action of proteinases (crystalline pepsin and trypsin) on proteins.

Results and discussion. Grain quality parameters of wild type and waxy accessions were compared. The yield, protein and starch contents, endosperm vitreousness, and antioxidant activity were shown to depend both on growing conditions and on genotypes. High nutritional quality of waxy barley cultivars was proved, videlicet, significantly higher content of oil compared with accessions with wild type starch and lower vitreousness of endosperm in chaffy accessions. Accessions with very valuable characteristics were selected: line 12-1014 with high digestibility of protein (61.75 mg tyrosine/g protein for pepsinolysis + trypsinolysis), line 12 945 with high antioxidant activity (2.02 $\mathrm{mg}$ chlorogenic acid equivalent/g), line 12-954 with a high content of oil (3.75\%) and awnless line 14-1183 with a high content of polyunsaturated $\omega-3$ linolenic acid (6.09\%). These lines are valuable both as starting material for the breeding of food cultivars, and directly for functional food production. Waxy cultivars Shedevr and Amil were submitted to the state variety trials. Grain of these cultivars is noticeable for high contents of starch $(>60 \%)$, oil $(3.45-3.47 \%)$ and fiber $(3.65-3.70 \%)$. Antioxidant activity is also sufficiently high (1.94-2.07 mg chlorogenic acid equivalent/g). Being low vitreous (40$43 \%$ ), cultivars Shedevr and Amil can be used for production of flakes and flour, including extruded flour.

Conclusions. Thus, the high nutritional value of barley varieties with modified starch composition was proven. High-nutrient lines, which are valuable both as starting material for the breeding of food varieties and directly for the production of functional foods, were distinguished. Varieties Shedevr and Amil were submitted to the State variety trials, and Shedevr has been entered in the State Register of Plant Varieties Suitable for Dissemination in Ukraine since 2019.

Key words: waxy starch, barley, amylose, amylopectin, antioxidant activity, protein content and digestibility, fatty acid composition of oil 